\title{
Kant and the general freedom of action
} Kant e a liberdade geral de ação

\author{
Fiete Kalscheuer ${ }^{1}$
}

\begin{abstract}
The legal philosophy of Immanuel Kant is complex and often confusing. Nevertheless Kant developed one of the most important liberal theories in the history of legal philosophy. The basic idea is simple: The necessity to protect the general freedom of action is the starting point of his Doctrine of Law. The only condition for this protection is that this freedom has to be compatible with the freedom of everybody else. Accordingly, for Kant even allegedly trivial actions belong to the realm of the judicial protection of the universal law of right. The question, which is to be answered in this essay, is: Why? - For what reason, Kant thinks, that there is the necessity to protect the general freedom of action.
\end{abstract}

Keywords: Immanuel Kant, general freedom of action, categorical imperative.

1 Cursou Direito em Greifswald, St. Petersburg e Kiel. Doutorou-se em Direito na Universidade de Kiel, junto à Cátedra de Direito Público e Filosofia do Direito, sob a supervisão de Robert Alexy. É advogado e leciona nos Cursos Preparatórios Alpmann-Schmidt, em Kiel. 
Resumo: A filosofia do direito de Immanuel Kant é complexa e muitas vezes confusa. Contudo, Kant desenvolveu uma das mais importantes teorias liberais na história da filosofia do direito. A ideia básica é simples: a necessidade de proteger a liberdade geral de ação é o ponto de partida da Doutrina do Direito. A única condição para essa proteção é que essa liberdade seja compatível com a liberdade de todos. Assim, para Kant, até mesmo ações triviais pertencem ao âmbito da proteção jurídica da lei universal do direito. A questão que pretende se responder neste ensaio é: Por que? - Por qual razão Kant acredita que a liberdade geral de ação deve ser protegida?

Palavras-chave: Immanuel Kant, liberdade geral de ação, imperativo categórico.

\section{Introduction}

It is common knowledge that Kant's ideas have had a major influence on the decisions of the Federal Constitutional Court of Germany concerning Art. 1 I of the German Basic Law, the dignity of man. The Federal Constitutional Court, relying on Kant's second formula of the categorical imperative, the end-in-itself-formula ${ }^{2}$, describes the rights and duties that follow from Art. 1 I of German Basic Law as follows:

2 The end-in-itself-formula says: "So act that you use humanity, whether in your own person or in the person of any other, always at the same time as an end, never merely as a means." (I. Kant, Groundwork of the Metaphysics of Morals, in The Cambridge Edition Of The Works Of Immanuel Kant Practical Philosophy, trans. and ed. M.J. Gregor [Cambridge: Cambridge University Press, 1996], 37 - 108 at AA 429). 
"Human dignity as such is affected when a concrete human being is reduced to an object, to a mere means, to a dispensable quantity." 3

A lesser-known fact is that the Federal Constitutional Court also interprets Art 2 I of the German Basic Law - the general right of freedom of action - in line with Kant's ideas. The Federal Constitutional Court for Germany understands regular legal practice as outlined in Art. 2 I of the German Basic Law as a basic right to universal freedom of action in a broad sense: Art. 2 I of the German Basic Law protects all human actions. ${ }^{4}$ This broad interpretation of Art 2 I of the German Basic Law is not without its critics.. In a famous dissenting opinion, Federal Constitutional Court Judge D. Grimm expressed the opinion that this broad interpretation of the extent of protection of Art 2 I of the German Basic Law would lead to a "banalization of basic rights" not intended by the Basic Law. ${ }^{5}$

The broad interpretation of the majority opinion of the Federal Constitutional Court, Art 2I of the German Basic Law corresponds to Kant's universal law of right ${ }^{6}$, the centerpiece of his legal Doctrine of Law. Through its application one can determine whether an action is legal or illegal. According to the universal law of right, an action is legal if the doer

3 BVerfGE 9, 89 (95); 27, 1 (6); 28, 386 (391); 50, 125 (133); 72, 105 (116); 87, 209 (228); 109, 279 (312). Regarding the question whether the recourse to Kant really is consistent with his ideas about human dignity, see F. Kalscheuer, Menschenwürde als Recht im Unrecht. Zur Ergänzungsfunktion der Menschenwürde im Recht bei Kant, in: Der Staat 2013 Bd. 52, Page 401 ff.

4 BVerfGE, Bd. 80, 137 (151 f.).

5 Sondervotum D. Grimm, BVerfGE, Bd. 80, 137 (165 ff.).

6 Kant's universal law of right says: "[S] act externally that the free use of your choice can coexist with the freedom of everyone in accordance with a universal law." (I. Kant, Groundwork of the Metaphysics of Morals, in The Cambridge Edition Of The Works Of Immanuel Kant - Practical Philosophy, trans. and ed. M.J. Gregor [Cambridge: Cambridge University Press, 1996] at 388). 
respects to the highest degree the freedom of others, to do or not to do, what he or she wants. Hence, the focus of the universal law of right is the protection of the external freedom of the individual. According to Kant, the only condition for this protection is that this freedom has to be compatible with the freedom of everybody else. Accordingly, for Kant even allegedly trivial actions belong to the realm of the judicial protection of the universal law of right.

Kant calls the right to generally do or not to do, what one wants, the only natural human right. With regard to this "restriction of the area of the natural human right to legally defined external freedom, Kant arguably stands alone in the history of ideas on human rights." 7

The obvious question is: what reason can be named to justify giving the universal freedom of action such huge significance that - at least prima facie - every action is considered worthy of legal protection? The prevailing juridical opinion on Art 2 I of the German Basic Law mainly answers this question by referring to the historical will of the parliamentary council, that demonstrably acted on the assumption of a broad understanding of the universal freedom of action. ${ }^{8}$ Kant, however, gives a philosophically grounded answer to the question of why universal freedom of action in general enjoys legal protection. What exactly Kant's answer is, is disputed and is the subject of this essay.

The question, why even allegedly trivial actions (should) benefit from legal protection, as long as they do not violate the rights of others, is therefore not (only) an academic intellectual game. ${ }^{9} \mathrm{~J}$. Ipsen justifiably called the dispute about

7 W. Kersting, Wohlgeordnete Freiheit. Immanuel Kants Rechts- und Staatsphilosophie, 1984, at 209.

8 V. Epping, S. Lenz, Grundrechte, 2014 Rn. 563 m. w. N.

9 It seems important to point this out explicitly. G. Geismann writes in his review of the dissertation "Autonomie als Grund und Grenze des Rechts" 
the extent of protection of the universal freedom of action "a first-rate problem of the dogma of basic rights as well as the theory of basic law." ${ }^{10}$ Further, his question is not only a matter of the aforementioned problems. Rather the decisions of the Federal Constitutional Court on Art. 2 I of the German Basic Law have direct effects, for example, on administrative law. Without the adjudication of the Federal Constitutional Court on Art. 2 I of the German Basic Law there could be no so-called "theory of addressee" 11 , which states that every incriminating administrative act entails the possibility of an infringement and therefore affirms a right of action according to $\S 42$ II of the German administrative code of procedure. It is only the general protection of the universal freedom of action that leads to the fact that every action by the state that burdens a citizen requires a justification and is subject to an examination by an independent court.

\section{On the value of the general freedom of action according to Kant}

According to the view presented in this essay, Kant's universal freedom of action is grounded in the idea, that every human being should be given a legally recognized area of protection that offers him or her the opportunity to

(F. Kalscheuer) im Philosophischen Literaturanzeiger 67/4/2014, p. 311 (319 that he has "strong" memories of "Kleists townjudge Adam", when reading the discussion about the question why, according to Kant, also supposed trivial actions benefit from legal protection. The statement by Geismann shows how important it is that the philosophy of law should not be left to pure philosophers alone, but to have legally skilled people dealing with it as well.

10 J. Ipsen, Staatsrecht II, Grundrechte, 2015, Rn. 771. § 42 Rn. 69 m. w. N.

11 Regarding the theory of addressee see exemplary Kopp/Schenke, VwGO Kommentar, 2015, § 42 Rn. 69 m.w.N. 
fulfill the moral responsibilities of the categorical imperative in the empirical-social world, i.e. in "real life." ${ }^{12}$ One may call this the "thesis of realization," 13 or perhaps more accurately, the "thesis of protection." 14 The thesis seem intuitively plausible: Autonomy, i.e. acting according to the categorical imperative, cannot be experienced on a sensual level, but it can at least become a reality in the empirical world as a "sensual sign."15 It stands to reason that this sensual sign is worth protecting. If there is a moral duty to perform a certain action, then a human being is commanded to fulfill that moral responsibility in the empirical-social world. Even though the thesis is immediately understandable, it has been subject to criticism. ${ }^{16}$

12 See F. Kalscheuer, Autonomie als Grund und Grenze des Rechts. Zum Verhältnis zwischen dem kategorischen Imperativ und dem allgemeinen Rechtsgesetz Kants, 2014, p. 206 ff.; a former author who defended this thesis is, among others, B. Bauch, Grundzüge der Ethik, 1968, p. 218; G. Dulckeit, Naturrecht und positives Recht bei Kant, 1932, p. 5; K.Larenz, Sittlichkeit und Recht, Untersuchungen zur Geschichte des deutschen Rechtsdenkens und zur Sittenlehre, Reich und Recht in der Deutschen Philosophie, Bd. I, p. 282; H.-L. Schreiber, Der Begriff der Rechtspflicht. Quellenstudien zu seiner Geschichte, 1968, p. 42 f.

13 R. Alexy, Ralf Dreiers Interpretation der Kantischen Rechtsdefinition, in: R. Alexy. (ed.), Integratives Verstehen. Zur Rechtsphilosophie Ralf Dreiers, 2005, p. 101 fn. 37; Kersting (fn. 6), p. 142, refers to this as a "moral-theological opinion".

14 Kalscheuer (fn. 11), p. 206, fn. 1143.

15 I. Kant, Kritik der reinen Vernunft, Akademieausgabe Bd. 3, 2. Aufl., 1907/1914, p. 574.

16 G. Geismann calls this thesis a "stale as well as an overcome thesis" that "in the future will inherit the same status within the philosophy of right as the thesis of 'horror vacui' of nature within phsysics" (G. Geismann, Recht und Moral in der Philosophie Kants, in Jahrbuch für Recht und Ethik, Bd. 14, Themenschwerpunkt: Recht und Sittlichkeit bei Kant, B. Sharon Byrd, Joachim Hruschka and Jan C. Joerden (eds.), 2006, p.3 (23)). For Geismanns Interpretation on Kant see H. Oberer, Rezension zu Georg Geismann: Kant und kein Ende (Bd.3: Pax Kantiana oder Der Rechtsweg zum Weltfrieden), Philosophischer Literaturanzeiger 66/4/2013, p. 348 ff. as well as H. Oberer, Noch einmal zu Kants Rechtsbegründung, Kant-Studien 2010, p. 380 ff. 
For some, the thesis cannot explain, why, according to Kant, ethically optional actions should also benefit from legal protection. ${ }^{17}$ If protecting the realization of moral duties in the empirical-social world were the task of the law, it would follow that any action which is optional according to the categorical imperative is legally irrelevant. Hence there would be no reason, according to the thesis of protection, to legally protect morally optional actions. There would be even less of a reason to legally protect (allegedly) immoral actions:

"Those who want to place drinking of beer or riding in the woods under legal protection, because it could be the expression of a morally bound maxim, would not want to give the same protection to actions, they consider morally forbidden (for example homosexuality or incest or active euthanasia). ${ }^{" 18}$

These objections to the thesis of protection refer to the scope of the judicial area of protection and with it the above-mentioned differences of opinion between the majority opinion of the Federal Constitutional Court and the opinion given by Federal Constitutional Court Judge D. Grimm in his dissenting vote: If one only wants to legally protect actions when they are the expression of moral-autonomous acts, it follows - according to the opinion of D. Grimm - that one should disregard entirely trivial actions. The thesis of protection thus corresponds - at least at first sight - more with $D$. Grimm's restrictive opinion than with the majority opinion of the Federal Constitutional Court and Kant's universal law of right, according to which any - including trivial (and even harmful) - actions at least prima facie enjoy judicial protection.

17 Alexy (fn. 7), p. 102 fn. 37; Kersting (fn. 6), p. 147 f.

18 Geismann (fn. 8), P. 321. 
Closely interwoven with the above-mentioned objection to the thesis of protection is the above-mentioned criticism that the thesis would degrade the law and turn it into the servant of morality. ${ }^{19} \mathrm{Kant}$, it is said, considered law and ethics to be equal. The thesis of protection on the other hand leads to an illegal moralization of the law, which Kant rejected. According to this view, the thesis of protection is "separated by an abyss" from Kant's Doctrine of Law. ${ }^{20}$

The aforementioned objections to the thesis of protection can be refuted..$^{21}$ The "problem," that according to Kant - allegedly in opposition to the thesis of protection - ethically optional (and possibly even ethically forbidden) actions also benefit from legal protection, can be dismissed by referencing Kant`s epistemic modesty in regards to questions of ethics (1.). The thesis of protection furthermore does not lead to an improper moralization of the law, because for factual reasons morality cannot be enforced anyway by means of coercion, i.e. judicially, and, in addition, must not be enforced for ethical reasons (2.).

\section{The universal law of right as an expression of ethical modesty}

The objection that the thesis of protection cannot explain the far-reaching extent of protection of the universal law of right discounts Kant`s epistemic reservation: According to Kant there are two epistemological problems when it comes to ethical actions. For one, it cannot be said with

19 Geismann (fn. 8), p. 319.

20 Geismann (fn. 8), p. 319.

21 A detailed rebuttal of all criticisms of the thesis of protection can be found in Kalscheuer (fn. 11), p. 206 ff. 
certainty, to what actions a person is actually ethically obligated. Secondly, it cannot be said with certainty, whether a person is acting ethically or not. Because it cannot even be determined with certainty within one`s own character what the actual driving force behind any given action is. ${ }^{22}$

The reason for Kant's epistemic reservation in questions of ethics can be found in the intelligibility of the categorical imperative - no assumption in the realm of experience corresponds to the categorical imperative. In other words: The categorical imperative is not, according to Kant, sensually experienceable and therefore cannot be applied to the empirical-social world immediately, i.e. schematically. It needs an indirect, i.e. symbolic, representation. ${ }^{23}$ The most important conclusion, which results from the only symbolically possible application of the categorical imperative to the empirical-social world, is this: According to Kant the categorical imperative itself cannot err, but a human being while trying to implement it can. ${ }^{24}$ Due to the only feasibly symbolic implementation of the categorical imperative it is, according to Kant, impossible to create a deductively justified catalog for a multitude of ethical responsibilities that is of

22 Kant (fn. 5), p. 392 f.: "For a human being cannot see into the depths of his own heart so as to be quite certain, even in a single action, of the purity of his moral intention and the sincerity of his deposition, even when he has no doubts about the legality of his action."

23 See I. Kant, Critique of practical reason, Akademieausgabe Bd. 5, 1908/1913, p. 352: "Every idea that are highlighted a priori with concepts are therefore schemes or symbols, the first of which includes direct and the second indirect presentations of the concept." Kant tries to achieve the symbolical presentation of the categorical imperative through the doctrine of typicality. See H. Bielefeldt, Kants Symbolik. Ein Schlüssel zu kritischen Freiheitsphilosophie, 2001, p. 54 ff.; H.J. Paton, Der Kategorische Imperativ, 1962, p. 189 ff.

24 See Kalscheuer (fn.11), p. 38 ff. 
timeless validity. ${ }^{25}$ In its application to the empirical-social world the categorical imperative thus does not offer "final solutions, but assists with drafting problems, which enable the judgmental assessment relating to the autonomous identification of actions." 26

Because of the epistemological problems connected to the utilization of the categorical imperative, and the unmanageable amount of possible ethical responsibilities in $\mathrm{Kant}^{27}$, it seems logical that he generally places all actions under legal protection, so long as they are compatible with everybody's universal freedom of action. According to Kant, the application of the categorical imperative in the empirical-social world does not lead to definitive ethical answers. As long as rights of others are not affected, it is therefore prohibited, to refuse to place actions under legal protection, which have with apparent certainty been identified as unethical. To put it positively: As long as the rights of others are not violated, it is necessary to place actions under legal protection, even if they have been identified with apparent certainty as unethical.

The universal law of right is therefore based on epistemological doubts; it is an expression of ethical modesty: Any action, which is compatible with everybody`s universal freedom of action, could (but does not have to) be an ethically demanded action and this justifies and demands that

25 H.-D. Klein, Formale und materiale Prinzipien in Kants Ethik, in: KantStudien Bd. 60(1969), p.183(186).

26 G. Luf, Die “Typik der reinen praktischen Urteilskraft” und ihre Anwendung auf Kants Rechtslehre, in Freiheit als Rechtsprinzip. Rechtsphilosophische Aufsätze, hrsg. v. Elisabeth Holzleithner u. Alexander Somek, 2008, p. 133(139).

27 According to Kant, it is an incomplete (moral) responsibility to develop the gifts given to one (Kant (fn. 1), p. 423). The concept of gift includes physical powers as well (Kant (fn. 5), p. 445; see Paton (fn. 22), p. 185). That is why every physical exercise - for example riding in the woods - is part of the potentially morally responsibilities of human beings. 
the complete range of external freedom of action is legally protected, as long as it is compatible with everybody`s universal freedom of action.

\section{No illegitimate moralization of the law}

As to the alleged illegitimate moralization of the law, which is supposedly entailed by the thesis of protection, it can be countered that this objection mistakes the essence of Kant's ideas of autonomy and morality: Both for factual and for normative reasons, which result from the essence of autonomy, the thesis of protection does not lead to an illegal moralization of the law.

The essence of autonomy lies in a human being following the categorical imperative, without being affected by external influences or necessities. To force a human being into ethical action would be, according to Kant, "a contradiction (in adjecto); because the latter would already include pressured freedom in its concept." 28 For Kant autonomous, i.e. ethical, action is , "an act of freedom" that, if enforced, would be "at the same moment not free" and would therefore invalidate itself. ${ }^{29}$ The coercion itself or the fear of force would lead to a human being performing a morally demanded action not based on the categorical imperative, i.e. for autonomous reasons, but rather for heteronomous, i.e. non-moral, reasons. According to Kant, morals can therefore not be enforced by coercion, i.e. legally. For this reason alone, the thesis of protection does not lead to an illegal moralization of the $\operatorname{law}^{30}$.

28 I. Kant, Religion within the Limits of Reason Alone, Akademieaugabe Bd. 6, 1907/1914, p. 95.

29 Kant (fn. 5), p. 381.

30 See Kalscheuer (fn.11), p. 213 f. 
Additionally it is - contrary to the opinion of the critiques of the thesis of protection - exactly the other way round: Precisely because the universal law of right finds its inner reason in the categorical imperative, in accordance with the thesis of protection, the thesis does not lead to an illegitimate moralization of the law. The derivation of the universal law of right from the categorical imperative rather means that the universal law of right has to be entirely free of morals. ${ }^{31}$ In other words: According to Kant, one cannot enforce morals by coercion, i.e. legally, and one is not allowed to enforce morals with force. ${ }^{32}$ "Every political common being" could indeed desire "that it would include in itself a control over the minds according to the laws of virtue," but due to the essence of autonomy this should never be enforced:

"Caution to the Legislator, who wants to create a constitution aimed at ethical purposes by coercion! Not only would he achieve the opposite of an ethical constitution, but he would undermine it politically and cause uncertainty within." ${ }^{33}$

For Kant moral autonomy will only be sufficiently protected if the human being - in H. Bielefeldt' $s^{34}$ words - has the opportunity "to 'withdraw' oneself to one`s legal right from the intrusiveness of an authoritarian social or public moralization, or, if need be, to hide behind the law."

31 According to Kant, the universal law of right is a law "that lays an obligation on me, but it does not at all expect, far less demand, that I myself should limit my freedom to those conditions just for the sake of this obligation" (Kant (fn. 5), p. 231).That the universal law of right Is to be seen as (morally) binding is, according to Kant, therefore no demand of the universal law of right itself, but a demand of morals: "That I make it my maxim to act rightly is a demand that ethics makes on me." (Kant (fn. 5), p. 231); see Kalscheuer (fn. 11), p. $98 \mathrm{ff}$.

32 See Kalscheuer (fn. 11), p. 217 ff.

33 Kant (fn. 27), p. 95f.

34 Bielefeldt (fn. 22), p. 111. 
The fact that the universal law of right refers to the categorical imperative as an inner cause, thus only ostensibly leads to the contradiction, that the universal law of right is not allowed to position itself on the morality of the individual. The legal right which follows from the universal law of right to force someone to abstain from a certain action, which unjustifiably encroaches on someone else`s area of protection of the universal freedom of action, may neither be based on morality of the person entitled to coerce nor on the (lack of) morality of the person subject to the coercion. ${ }^{35}$

In this context, the following must be taken in consideration: Only the deduction of the universal law of right from the categorical imperative can explain why Kant attaches such a great degree of importance to the law, that he describes "the right of human beings" as "the most sacred [...] that God has on earth;"36 it is only by acknowledging the correlation of derivation between law and morals that it is possible to explain why Kant declares the right of human beings to be "the apple of God 's Eye" ${ }^{\prime 37}$. It is not that an abyss separates Kant's doctrine of law from the advocates of the thesis of protection, but rather it is the other way around: Those who assume that the categorical imperative and the universal law of right are independent from one another degrade the law. They fail to understand that the universal law of right draws its inner worth from the categorical imperative.

35 Kalscheuer (fn. 11), p. $213 \mathrm{f}$.

36 I. Kant. Toward Perpetual Peace, in The Cambridge Edition Of The Works Of Immanuel Kant - Practical Philosophy, trans. and ed. M.J. Gregor [Cambridge: Cambridge University Press, 1996], p. 325.

37 Ibid. 


\section{Conclusion}

There are, in accordance with everything that has been said in this essay, two arguments that - originating from the thesis of protection - could explain why for Kant - at least prima facie - the entirety of the universal freedom of action is legally protected: an epistemological-factual argument and a normative one. The epistemological-factual argument for the protection of the universal freedom of action is that morality cannot be enforced by coercion. After all, it cannot be said with certainty whether or not a human being acts morally; even if one could identify the morality of an action, it could not be enforced by coercion. The normative argument - connected to the epistemological-factual argument - rests on Kant`s understanding that it would be morally illegitimate to try to enforce morality by force. This would contradict the essence of moral autonomy, which is based on the absence of external coercion.

The thesis of protection supported in this essay subsequently illustrates that in the disagreement about the interpretation of Art. 2 I German Basic Law - originating from Kant - both the majority opinion of the Federal Constitutional Court of Germany and the opinion by D. Grimm, in his dissenting vote, contain a bit of truth. D. Grimm 's opinion, according to which Art. 2 I German Basic Law as per the wording deals with personal development and thus with developmental opportunities of human beings as moral-autonomous beings, has to be agreed with in principle. Regarding the extent of Art. 2 I of the German Basic Law the majority opinion of the Federal Constitutional Court of Germany is also right: Due to epistemological-factual and normative reasons, the decision as to what is especially important for personal development can only be made by the subject of fundamental rights alone. 
That is why the entirety of external freedom of action of human beings is worthy of legal protection.

Recebido em 23/04/2019.

Aprovado em 23/04/2019.

Kiel Fiete Kalscheuer 
